\title{
Acute Response Moderate Intensity Treadmill Training On Decrease Malondialdehyde in Obesity Women
}

\author{
Septiana Choerul Anam ${ }^{1}$, Sulistiawati ${ }^{2}$, Bambang Purwanto ${ }^{13 *}$ \\ ${ }^{I}$ Sport Health Science Study Program, Faculty of Medicine Universitas Airlangga \\ ${ }^{2}$ Department of Public Health Sciences Preventive Medicine (IKM-KP) Faculty of Medicine \\ Universitas Airlangga \\ ${ }^{3}$ Department of Physiology Faculty of Medicine Universitas Airlangga \\ *bpaifo@gmail.com
}

\begin{abstract}
Obesity is often associated with increased oxidative stress. Malondialdehyde (MDA) is the final product of fat peroxidation that can be used as a biological bio maker of fat peroxidation and it is used to describe the degree of oxidative stress. This study aims to analyze the acute response of moderate intensity treadmill exercise to a decrease in MDA levels in obese women. This study used a true experiment research method with the randomized control group design posttest-only design using 21 obese women and randomly divided into three groups, namely $\mathrm{K} 1$ ( $\mathrm{n}=7$, control without intervention), $\mathrm{K} 2$ $(\mathrm{n}=7$, moderate intensity interval training) and $\mathrm{K} 3(\mathrm{n}=7$, moderate intensity continuous training). The intervention was carried out at 07.00-10.00 a.m. Moderate intensity interval training interventions were carried out for 45 minutes, whereas moderate intensity continuous training were carried out for 40 minutes. Blood samples were taken 10 minutes after the intervention. MDA levels were measured using the Thiobarbituric Acid Reactive substance (TBARs) method. Data analysis techniques using ANOVA test and LSD post hoc test with the Statistical Package for Social Science (SPSS). The results were obtained at $\mathrm{K} 1(811.286 \pm 72.539) \mathrm{ng} / \mathrm{mL}, \mathrm{K} 2(615.571 \pm 96.855) \mathrm{ng} / \mathrm{mL}, \mathrm{K} 3(658.429 \pm 113.934)$ $\mathrm{ng} / \mathrm{mL}$ and $(\mathrm{p}=0.003)$. Based on the results of the study, it was concluded that the acute response of moderate intensity interval training significantly reduced MDA levels compared to moderate intensity continuous and control in obese women.
\end{abstract}

Keywords: Moderate intensity interval exercise, moderate intensity continuous exercise, malondialdehyde, obese women. 


\section{STRADA Jurnal Ilmiah Kesehatan}

DOI: $10.30994 /$ sjik.v9i2.301

ISSN: 2252-3847 (print); 2614-350X (online)

Vol.9 No.2 November 2020 Page.358-367

\section{BACKGROUND}

Prevalence rates are increasingly difficult at alarming rates both in developed and developing countries (Norheim et al., 2014). It is estimated that $13 \%$ of the world's population selected over 18 years old is stunted (WHO, 2016). In Indonesia based on the results of the Basic Health Research (RISKESDAS) in 2018 the prevalence of obesity in adults at 18 years increased in 2007 reaching 10.5\%, in 2013 reaching $14.8 \%$ and the prevalence in 2018 reaching $21.8 \%$ of the total population of Indonesia. The increasing prevalence of obesity has been very worrying and poses a very serious threat to health (Peterson et al., 2014). Obesity often increases with oxidative stress (Huang et al., 2015). Increased-oxidative stress increases the risk of heart disease and leading to cause death (Esgalhado et al., 2015). However, this is not resolved properly.

Increased-oxidative stress in the body correlates with the pathogenesis of various degenerative diseases (Ardhie, 2011) such as diabetes mellitus, cancer (Bloomer et al., 2005), stroke (Hairrudin and Helianti, 2009), chronic kidney disease (CKD) (Esgalhado et al., 2005), 2015). Oxidative stress is an imbalance between the productions of free radicals with antioxidants (Arsana et al., 2013). Therefore, we need one of the methods required for exercise-based non-pharmacology that can be used to get the balance of free radical production with antioxidants (Esgalhado et al., 2015; Pingitore, 2015). One of the methods is very effective and efficient in preventing increased oxidative stress (Wilund et al., 2010). Recent studies have shown how to reduce oxidative stress and enhance antioxidant defense systems in the body (Wilund et al., 2010; Gordon et al., 2008). This relates to the results of research conducted by Mrakic-Sposta et al. (2015) concluded that exercise carried out with the right dose increases antioxidants by $13 \%$ and decreases the reactive oxygen system (ROS) by $20 \%$.

Exercise can reduce the production of free radicals by increasing the mechanism of proteasome activity and DNA repair enzymes, decreasing DNA binding with redox sensitive transcription factors such as (NF- $\mathrm{BB}, \mathrm{AP}-1, \mathrm{MAPK}$ and CREB) and increasing production of GPx and MnSOD can cause hormones in the body so it causes an increase in antioxidants and a decrease in free radicals (Pingitore, 2015; Candrawati, 2014; Cabrera et al., 2007). Previous studies have yielded results as diverse as the studies conducted by Esgalhado et al. (2018) concluded that acute intradialytic strength physical exercise reduces oxidative stress and increases superoxide dismutase (SOD). Likewise research conducted by Vezzoli et al. (2014), concluded that moderate-intensity continuous training significantly reduces oxidative stress and increases antioxidants. However, exercise also has the potential to increase oxidative stress and reduce antioxidants (Huang et al., 2015; Moflehi et al., 2012). Proven in research conducted by Algul et al. (2018) concluded that acute aerobic exercise significantly increases oxidative stress reviewed from elevated serum Malondialdehyde (MDA) levels. Likewise research conducted by Moflehi et al. (2012) concluded that aerobic exercise significantly increased serum MDA levels. MDA is one of the end products of fat peroxidation which is used as a biological bio maker of fat peroxidation that can be used to describe the degree of oxidative stress. Measuring MDA levels also includes measuring free radical activity (Rahardjani, 2010). So far the acute response of moderate intensity treadmill training to the reduction in MDA levels is still unclear, so researchers took this intervention as something for further research. 


\section{STRADA Jurnal Ilmiah Kesehatan}

DOI: $10.30994 /$ sjik.v9i2.301

ISSN: 2252-3847 (print); 2614-350X (online)

Vol.9 No.2 November 2020 Page.358-367

On the basis of the above background, the aim of this study is to analyze the acute response of moderate intensity treadmill exercise to the reduction in MDA levels of obese women.

\section{METHODS}

This study used a true experiment research method with the randomized control group design posttest-only design using 21 obese women and randomly divided into three groups, namely $\mathrm{K}_{1}\left(\mathrm{n}=7\right.$, control without intervention), $\mathrm{K}_{2}(\mathrm{n}=7$, moderate intensity interval training) and $\mathrm{K}_{3}(\mathrm{n}=7$, moderate intensity continuous training). All research procedures were approved by the Health Research Ethics Commission of the Faculty of Medicine Airlangga University number 309/EC/KEPK/FKUA/2019.

Moderate intensity interval exercises were performed for 45 minutes ( 5 warm up; 35 minutes core and 5 minutes cool down), while moderate intensity continuous exercise was carried out for 40 minutes (5 warm up; 30 minutes core and 5 minutes cool down). Moderate intensity and continuous interval training are performed using the richter semicommercial revolution treadmill $(4.0 \mathrm{hp} \mathrm{dc})$. The intervention was carried out at $07.00-$ 10.00 a.m.

Measurement of percentage body fat (PBF), fat free mass (FFM) and fat mass (FM) were using the DC-360 tanita body composition analyzer. Measurement of height (TB) and weight (BB) were using the scales of GEA ZT-120. Measurement of body mass index (BMI) by calculating body weight $(\mathrm{kg})$ and divided by height in meters squared $(\mathrm{m} 2)$. Blood drawn before and 10 minutes after the intervention. Measurement of Malondialdehyde (MDA) levels using the Thiobarbituric Acid Reactive substance (TBARs) method (Esgalhado et al., 2015).

Statistical analysis was using statistical software packages for social science (SPSS). The normality test uses the Shapiro-Wilk test, while the homogeneity test uses the Levene test. Data that were normally distributed and had a homogeneous variant were tested using the ANOVA test and continued with a post hoc LSD test with a significant level $(P<0.05)$. All data are displayed with mean \pm SD.

\section{RESULT}

The results of descriptive analysis of the research subjects characteristics in each group can be seen in table 1 .

Table 1. Characteristics of Research

\begin{tabular}{|c|c|c|c|c|}
\hline \multirow{2}{*}{ Variable } & \multicolumn{3}{|c|}{ Group } & \multirow{2}{*}{$\begin{array}{l}\text { ANOVA } \\
p \text {-value }\end{array}$} \\
\hline & $\mathbf{K}_{1}$ & $\mathbf{K}_{2}$ & $\mathbf{K}_{\mathbf{3}}$ & \\
\hline Age (year) & $20.67 \pm 1.03$ & $21.00 \pm 1.41$ & $20.67 \pm 0.82$ & 0.838 \\
\hline Weight (kg) & $75.23 \pm 6.74$ & $72.30 \pm 9.27$ & $72.32 \pm 8.60$ & 0.782 \\
\hline Height (meter) & $1.58 \pm 0.05$ & $1.57 \pm 0.07$ & $1.57 \pm 0.06$ & 0.912 \\
\hline 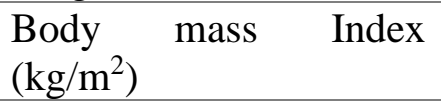 & $29.85 \pm 1.60$ & $28.85 \pm 1.99$ & $29.02 \pm 1.58$ & 0.576 \\
\hline $\begin{array}{l}\text { Percentage Body Fat } \\
(\%)\end{array}$ & $45.47 \pm 3.17$ & $43.47 \pm 2.49$ & $43.82 \pm 2.59$ & 0.430 \\
\hline Fat Free Mass (kg) & $36.01 \pm 6.14$ & $31.27 \pm 5.29$ & $31.93 \pm 4.85$ & 0.218 \\
\hline Fat Mass (kg) & $41.37 \pm 4.05$ & $41.53 \pm 4.48$ & $40.06 \pm 3.06$ & 0.720 \\
\hline
\end{tabular}




\section{STRADA Jurnal Ilmiah Kesehatan}

DOI: $10.30994 /$ sjik.v9i2.301

ISSN: 2252-3847 (print); 2614-350X (online)

Note: $\mathrm{K}_{1}$ : control group; $\mathrm{K}_{2}$ : moderate intensity interval training group; $\mathrm{K}_{3}$ : moderate intensity continuous training group.

Based on the results of the study showed that the average characteristics of the research subjects in each group had several differences. Based on ANOVA test results showed that all characteristics of the study subjects did not show significant differences $(P>0.05)$. Therefore, if there is a change in MDA levels, it is not due to the characteristic factors of the study subjects, it is likely due to the intervention factors of moderate interval training and continuous intensity. Data from MDA level analysis results can be seen in Figure 1.

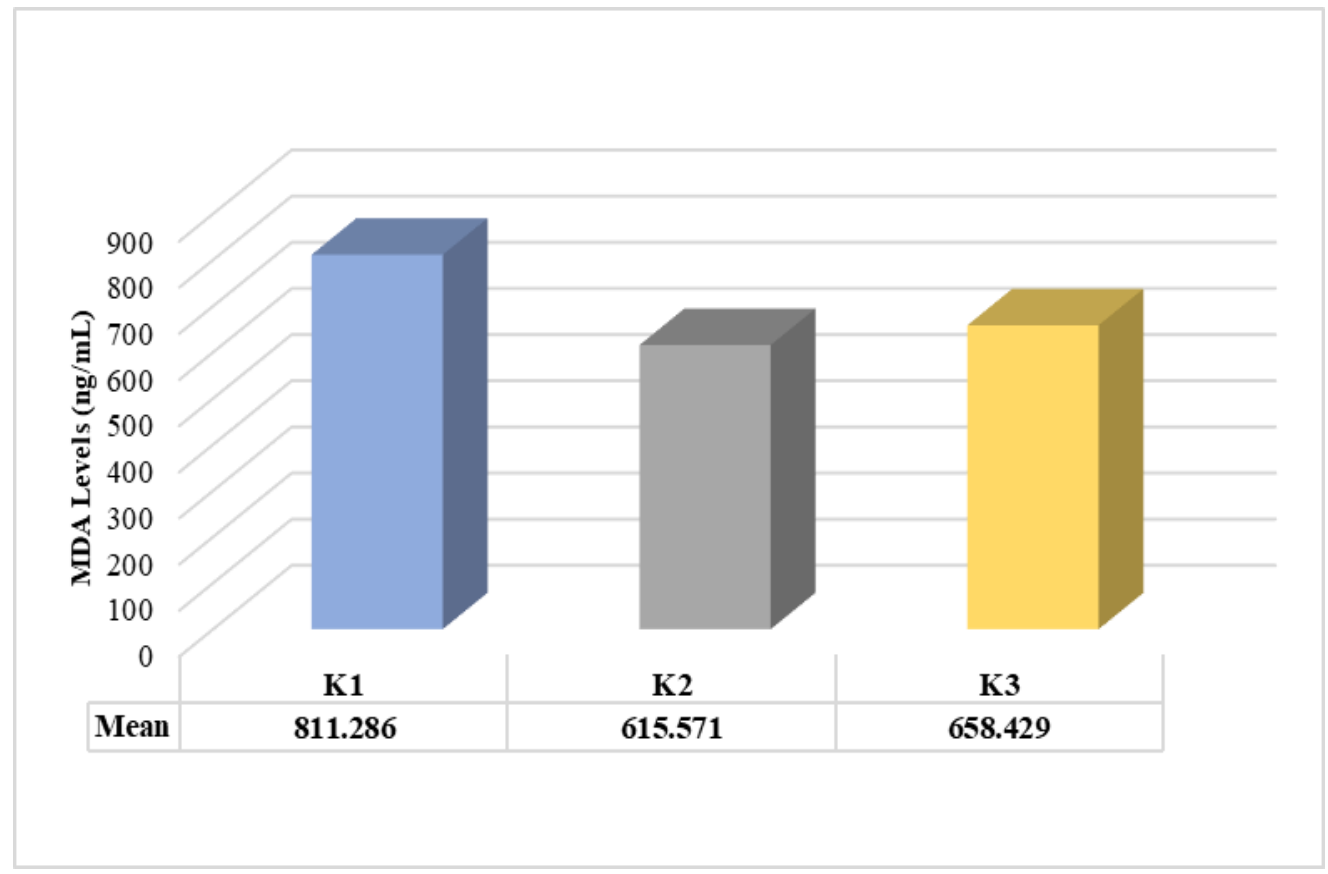

Figure 1. Graph of Average MDA Levels in Each Group

Based on Figure 1 shows that the average MDA level in $K_{2}$ is lower compared to $K_{3}$ and $K_{1}$. To see whether it is significant or not, difference from each group, the ANOVA test was performed. ANOVA test results can be seen in table 2 .

Table 2. Results of MDA Level Analysis in Each Group

\begin{tabular}{|c|c|c|c|c|c|}
\hline Kelompok & $\mathbf{n}$ & $\begin{array}{c}\text { Mean } \pm \text { SD } \\
(\mathrm{ng} / \mathrm{mL})\end{array}$ & $\begin{array}{c}\text { Normalitas } \\
\text { p-value }\end{array}$ & $\begin{array}{c}\text { Homogenitas } \\
\text { p-value }\end{array}$ & $\begin{array}{l}\text { ANOVA } \\
\text { p-value }\end{array}$ \\
\hline $\mathbf{K}_{\mathbf{1}}$ & 7 & $811.286 \pm 72.539^{a}$ & 0.101 & \multirow{3}{*}{0.198} & \multirow{3}{*}{$0.003^{*}$} \\
\hline $\mathbf{K}_{2}$ & 7 & $615.571 \pm 96.855^{b}$ & 0.196 & & \\
\hline $\mathbf{K}_{\mathbf{3}}$ & 7 & $658.429 \pm 113.934^{b}$ & 0.516 & & \\
\hline
\end{tabular}




\section{STRADA Jurnal Ilmiah Kesehatan}

DOI: $10.30994 /$ sjik.v9i2.301

ISSN: 2252-3847 (print); 2614-350X (online)

Vol.9 No.2 November 2020 Page.358-367

Based on ANOVA test results showed that there are significant differences in the average MDA level $(\mathrm{p}=0.003)$. Based on the results of the post hoc LSD test, there are significant differences in MDA levels between $\mathrm{K}_{2}$ and $\mathrm{K}_{1}(\mathrm{p}=0.001), \mathrm{K}_{3}$ and $\mathrm{K}_{1}(\mathrm{p}=0.008)$, while $\mathrm{K}_{2}$ and $\mathrm{K}_{3}$ did not have a significant difference $(\mathrm{p}=0.414)$.

\section{DISCUSSION}

Based on the results of the study (Table 1) shows that the average characteristics of the study subjects in each group did not show a significant difference $(P>0.05)$. These results are in line with the results of research conducted by Algul et al. (2018) concluded that there were no significant differences in the mean data characteristics of study subjects which included age, TB, BB, FFM and FM $(P>0.05)$. Likewise the research that conducted by Cardoso et al. (2012) showed that there were no significant differences in data on subject characteristics including age, TB, BB, BMI, PBF and FM $(P>0.05)$. Therefore, if there is a change in MDA levels it is not due to the characteristic factors of the study subjects, it is likely due to the intervention factors of moderate interval training and continuous intensity.

Obesity which often associated with increased-oxidative stress (Huang et al., 2015). Malondialdehyde (MDA) is one of the end products of fat peroxidation that used as a biological bio maker of fat peroxidation and can be used to describe the degree of oxidative stress (Rahardjani, 2010). MDA is a toxic compound resulting from the breaking of the fatty acid carbon chain in the lipid peroxidation process (Andiana, 2011). The increase in MDA indicates the existence of a fat peroxidation process that has the potential for complications both micro and macro vascular (Marjani, 2010). The increase in MDA can be caused by training (Candrawati, 2013; Andiana and Prasetyo, 2011). However, based on the results of the study (Figure 1) shows that MDA levels in $\mathrm{K}_{2}$ are lower compared to $\mathrm{K}_{3}$ and $\mathrm{K}_{1}$. LSD post hoc test results showed that there were significant differences in MDA levels between $\mathrm{K}_{2}$ and $\mathrm{K}_{1}(\mathrm{p}=0.001)$. These results are in line with the results of a study conducted by Esgalhado et al. (2015) concluded that strength training performed acutely decreases oxidative stress and increases antioxidants in women with normal BMI. Likewise the research that conducted by Mrakic-Sposta et al. (2015) concluded that exercise which done regularly with the right dose increases antioxidants by $13 \%$ and decreases ROS by $20 \%$. The decrease in MDA levels as an indicator of oxidative stress levels in $\mathrm{K} 2$ is likely due to the effect of exercise. This is because exercise can reduce the production of free radicals by increasing the mechanism of proteasome activity and DNA repair enzymes, decreasing DNA binding with redox sensitive transcription factors such as (NF-KB, AP-1, MAPK and CREB) and increasing production of GPx and MnSOD can cause Hormesis in the body thus causing an increase in antioxidants and a decrease in free radicals (Pingitore, 2015; Candrawati, 2014; Cabrera et al., 2007).

Based on the results of the study showed that no significant difference in MDA levels between $\mathrm{K}_{2}$ and $\mathrm{K}_{3}(\mathrm{p}=0.414)$. However, based on the average value of MDA levels in $\mathrm{K}_{3}$ it tends to be higher than the average value of $\mathrm{K}_{2}$ (Table 2). The increase in MDA levels in $\mathrm{K}_{2}$ is likely because during the exercise, oxygen demand increases 10 to 20 times and oxygen to the muscles increases 100 to 200 times (Candrawati, 2013; Sen, 1995). When oxidative phosphorylation is in the mitochondria, oxygen is reduced by the mitochondrial electron transport system for the formation of adenosine triphosphate (ATP) and water (H2O) (Mrakic-Sposta et al., 2015). In oxidative phosphorylation (electron transport) as much as $2-5 \%$ of the total oxygen demand can be converted into free radicals to produce ROS (Anita, 2014; Arsana et al., 2013). In addition, exercise that is done with 


\section{STRADA Jurnal Ilmiah Kesehatan}

DOI: $10.30994 / \mathrm{sjik} . v 9 i 2.301$

ISSN: 2252-3847 (print); 2614-350X (online)

Vol.9 No.2 November 2020 Page.358-367

heavy intensity with the wrong dose can increase ROS production, reduce antioxidants and increase oxidative stress. Increased ROS production and decreased antioxidant production can increase lipid peroxidation which has an impact on increasing MDA production (Pingitore, 2015).

\section{CONCLUSION}

Based on the results of the study it can be concluded that moderate intensity interval training using a treadmill conducted for 45 minutes/training session significantly decreases MDA levels in obese women. The acute response to moderate intensity interval training has a positive effect in reducing MDA levels compared to moderate intensity continuous training and control in obese women. Based on the results of the study it is recommended that further research be carried out by providing interval training interventions and moderate intensity which is carried out chronically. Add other parameters such as Superoxide Dismutase (SOD) to describe the level of antioxidants in the body. 


\section{STRADA Jurnal Ilmiah Kesehatan}

DOI: $10.30994 /$ sjik.v9i2.301

ISSN: 2252-3847 (print); 2614-350X (online)

Vol.9 No.2 November 2020 Page.358-367

\section{REFERENCES}

Algul, S., Ugras, S. and Kara, M. 2018. Comparative evaluation of MDA levels during aerobic exercise in young trained and sedentary male subjects. East $J$ Med, 23(2): 98-101. https://doi.org/10.5505/ejm.2018.40469.

Andiana, O. and Prasetyo, Y. 2011. Pengaruh Latihan Interval Istirahat Aktif dan Istirahat Pasif Terhadap Derajat Stres Oksidatif. Buletin Penelitian Sistem Kesehatan, 14(3): 249-257.

Anita, D.C. 2014. Kadar Glukosa Darah dan Malondialdehid Ginjal Tikus Diabetes yang Diberi Latihan Fisik. Muhammadiyah Journal of Nursing, 109-116.

Ardhie, A.M. 2011. Radikal Bebas dan Peran Antioksidandalam Mencegah Penuaan. Medicinus, 24(1): 1-64.

Arsana, I.N., Adiputra, N., Pangkahila, J.A. and Putra-Manuaba, I.B. 2013. Garcinia Mangostana L.Rind Extract And Physical Training Reduce Oxidative Stress In Wistar Rats During Maximal Physical Activity. Indonesian Journal of Biomedical Sciences, 7(2): 63-68.

Bailey D.A., Lawrenson L., McEneny J., Young, I.S., James, P.E., Jackson, S.K., Henry,

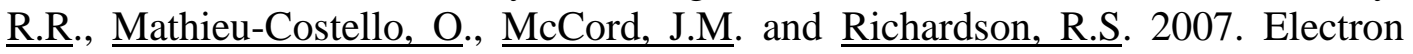
paramagnetic spectroscopic evidence of exercise-induced free radical accumulation in human skeletal muscle. Free Radical Research, 41(2): 182-190. https://doi.org/10.1080/10715760601028867.

Bloomer, R.J., Goldfarb, A.H. and Mckenzie, M.J. 2005. Oxidative Stress Response toAerobic Exercise: Comparison ofAntioxidant Supplements. Medicine \& Science In Sports \& Exercise, 1098-1105.

Cabrera, M.C.G, Domenech. E. and Vina, J. 2007. Moderat Exercise is an Antioxidant: Upregulation of Antioxidant Genes by Training. Free Radical Biology \& Medicine, 44(1): 126-131.

Candrawati, S. 2013. Pengaruh Aktivitas Fisik terhadap Stres Oksidatif. Jurnal Mandala of Health, 6(1): 454-461

Cardoso, A.M., Bagatini, M.D., Roth, M.A., Martins, C.C., Rezer, J.F.P., Mello, F.F., Lopes, L.F.D., Morsch V.M. and Schetinger, M.R.C. 2012. Acute effects of resistance exercise and intermittent intense aerobic exercise on blood cell count and oxidative stress in trained middle-aged women. Braz J Med Biol Res, 45(12): 11721182. https://doi.org.10.1590/S0100-879X2012007500166.

Esgalhado, M., Stockler-Pinto, M.B., de França Cardozo, L.F.M., Costa, C., Barboza, J.E. and Mafra, D. 2015. Effect of acute intradialytic strength physical exercise on oxidative stress and inflammatory responses in hemodialysis patients. Kidney Res Clin Pract, 34: 35-40. http://dx.doi.org/10.1016/j.krcp.2015.02.004. 


\section{STRADA Jurnal Ilmiah Kesehatan}

DOI: $10.30994 /$ sjik.v9i2.301

ISSN: 2252-3847 (print); 2614-350X (online)

Vol.9 No.2 November 2020 Page.358-367

Finaud, J., Lac, G. and Filaire, E. 2007. Oxidative stress: relationship with exercise and training. Sports Medicine, 36(4):327-358. https://doi.org/10.2165/00007256200636040-00004.

Gadde, K. M., Martin, C. K., Berthoud, H-R. and Heymsfield, S. B. 2018. Obesity: Pathophysiology and Management. Journal of The American College of Cardiology, 71(1): pp. 69-84. https://doi.org/10.1016/j.jacc.2017.11.011.

Gordon, L.A., Morrison, E.Y., McGrowder, D.A., Young, R., Fraser, Y.T.P., Zamora, E.M., Alexander-Lindo, R.L. and Irving, R.R. 2008. Effect of exercise therapy on lipid profile and oxidative stress indicators in patients with type 2 diabetes. BioMed Central. 8(21): 1-10.

Hairrudin and Helianti, D. 2009. Efek Protektif Propolis Dalam Mencegah Stres Oksidatif Akibat Aktifitas Fisik Berat (Swimming Stress) 'Propolis' Protective Effect to Prevent Oxidative Stress Caused by Strenous Physical Activity (Swimming Stress). Jurnal Ilmu Dasar, 10(2): 207-211.

Huang, C-J., McAllister, M.J., Slusher, A.L., Webb, H.E., Mock, T. and Acevedo, E.O. 2015. Obesity-Related Oxidative Stress: the Impact of Physical Activity and Diet Manipulation. Sports Medicine - Open, 1(32) 1-12. https://doi.org/10.1186/s40798015-0031-y.

Moflehi, D., Kok, L.Y., T-K, T.F and Amri, S. 2012. Effect of Single-Session Aerobic Exercise with Varying Intensities on Lipid Peroxidation and Muscle-Damage Markers in Sedentary Males. Global Journal of Health Science, 4(4).

Mrakic-Sposta, S., Gussoni, M., Porcelli, S., Pugliese, L., Pavie, G., Bellistri, G., Montorsi, M., Tacchini, P. and Vezzoli, A. 2015. Training Effect on Production Determined by Electron Paramagnetic Resonance in Master Swimmers. Oxidative Medicine and Cellular Longevity, 2015: 804794 https://doi.org/10.1155/2015/804794.

Nimptsch, K., Konigorski, S. and Pischon, T. 2019. Diagnosis of obesity and use of obesity biomarkers in science and clinical medicine. Journal of Metabolism Clinical and Experimental, 92: pp. 61-70.

Nimptsch, K. and Pischon, T. 2015. Body fatness, related biomarkers and cancer risk: an epidemiological perspective. Horm Mol Biol Clin Invest, 22: pp. 39-51.

Norheim, F. Langleite, T.M., Hjorth, M., Holen, T., Kielland, A., Stadheim, H.K., Gulseth, H.L., Birkeland, K.I., Jensen, J. and Drevon, C.A. 2014. The effects of acute and chronic exercise on PGC-1 $\alpha$, irisin and browning of subcutaneous adipose tissue in humans. FEBS Journal, 281(3). pp. 739-749. https://doi.org/10.1111/febs.12619.

Peterson, J.M., Mart, R. and Bond, C.E. 2014. Effect of obesity and exercise on the expression of the novel myokines, Myonectin and Fibronectin type III domain containing 5. PeerJ, 2:e605. https://doi.org/10.7717/peerj.605. 


\section{STRADA Jurnal Ilmiah Kesehatan}

DOI: $10.30994 /$ sjik.v9i2.301

ISSN: 2252-3847 (print); 2614-350X (online)

Vol.9 No.2 November 2020 Page.358-367

Pingitore, A., Lima, G.P.P., Mastorchi, F., Quinones, A., Iervasi, G. and Vassalle, C. 2015. Exercise and Oxidative Stress: Potential Effect of Antioxidant Dietary Strategies in Sport. Journal Nutrition, 31: 916-922.

Powers, S.K. and Jackson, M.J. 2008. Exercise-induced oxidative stress: cellular mechanisms and impact on muscle force production. Physiological Reviews, 88(4): 1243-1276. https://doi.org/10.1152/physrev.00031.2007.

Rahardjani, K.B. 2010. Hubungan antara Malondialdehyde (MDA) dengan Hasil Luaran Sepsis Neonatorum. Jurnal Sari Pediatri, 12(2): 82-87.

Riskesdas. 2018. Laporan Nasional Riset Kesehatan Dasar. Jakarta: Kemenkes RI. Available at: http://www.kesmas.kemkes.go.id.

Sachdev S. and Davies K.J.A. 2008. Production, detection, and adaptive responses to free radicals in exercise. Free Radical Biology \& Medicine, 44(2): 215-223. https://doi.org/10.1016/j.freeradbiomed.2007.07.019.

Sen, C.K. 1995. Oxidants and antioxidants in exercise. Journal of Applied Physiology, 79(3): 675-686.

Vezzoli A., Pugliese L., Marzorati M., Serpiello F. R., La Torre A. and Porcelli S. Timecourse changes of oxidative stress response to high-intensity discontinuous training versus moderate-intensity continuous training in masters runners. PLoS ONE, 9(1): e87506 https://doi.org/10.1371/journal.pone.0087506.e87506.

Wilund, K.R., Tomayko, M.J., Wu, P-T., Chung, H.R., Vallurupalli, S., Lakshminarayanan, B. and Fernhall, B. 2010. Intradialytic exercise training reduces oxidative stress and epicardial fat: a pilot study. Nephrol Dial Transplant, 25: 2695-20701. https://doi.org/10.1093/ndt/gfd106.

World Health Organization (WHO). 2016. Obesity and overweight. Diakses 02 Januari 2020 dalam http://www.who.int/mediacentre/factsheets/fs311/en/.

Rahardjani, K.B. 2010. Hubungan antara Malondialdehyde (MDA) dengan Hasil Luaran Sepsis Neonatorum. Jurnal Sari Pediatri, 12(2): 82-87.

Riskesdas. 2018. Laporan Nasional Riset Kesehatan Dasar. Jakarta: Kemenkes RI. Available at: http://www.kesmas.kemkes.go.id.

Sachdev S. and Davies K.J.A. 2008. Production, detection, and adaptive responses to free radicals in exercise. Free Radical Biology \& Medicine, 44(2): 215-223. https://doi.org/10.1016/j.freeradbiomed.2007.07.019.

Sen, C.K. 1995. Oxidants and antioxidants in exercise. Journal of Applied Physiology, 79(3): 675-686. 


\section{STRADA Jurnal Ilmiah Kesehatan}

DOI: $10.30994 /$ sjik.v9i2.301

ISSN: 2252-3847 (print); 2614-350X (online)

Vol.9 No.2 November 2020 Page.358-367

Vezzoli A., Pugliese L., Marzorati M., Serpiello F. R., La Torre A. and Porcelli S. Timecourse changes of oxidative stress response to high-intensity discontinuous training versus moderate-intensity continuous training in masters runners. PLOS ONE, 9(1): e87506 https://doi.org/10.1371/journal.pone.0087506.e87506.

Wilund, K.R., Tomayko, M.J., Wu, P-T., Chung, H.R., Vallurupalli, S., Lakshminarayanan, B. and Fernhall, B. 2010. Intradialytic exercise training reduces oxidative stress and epicardial fat: a pilot study. Nephrol Dial Transplant, 25: 2695-20701. https://doi.org/10.1093/ndt/gfd106.

World Health Organization (WHO). 2016. Obesity and overweight. Diakses 02 Januari 2020 dalam http://www.who.int/mediacentre/factsheets/fs311/en/. 